\title{
ANALYSIS OF THE CAPABILITIES OF THE DETECTION OF UNDERGROUND OPTICAL LINES USING GROUND PENETRATING RADAR SCANNING TECHNOLOGY
}

\author{
Vladan Bajčeta'
}

Received: November 15, 2017 | Accepted: December 10, 2017

\begin{abstract}
Optical telecommunication lines (fiber optic) are used to transfer large amounts of information and are most commonly constructed with non metallic materials. On a selected optical line route, measurements were made using Ground Penetrating Radar technology. Antennas with central frequencies of $400 \mathrm{MHz}$ and $900 \mathrm{MHz}$ were used for the purpose of this study. Based on the obtained data, a conclusion was made about the capability of Ground Penetrating Radar to detect undergroundfiber optic lines.
\end{abstract}

Keywords: underground fiber optics, GPR, central frequency of antenna, detection

\section{INTRODUCTION}

A record of existing subsurface utilities is kept and maintained in the national caster. In order for the astral records to be kept up to date, mapping and localization of underground infrastructure is essential. For this purpose, detection of underground utilities can be performed using Non-Destructive testing - NDT such as the use of Ground-penetrating radar (GPR).

Optical fiber cables represent a form of telecommunication lines which, through the use of modulated light impulses convey large amounts of information. They are mostly constructed from non-metallic materials (plastic, polymers, glass). Considering the construction materials and the large depth at which the optical lines are buried, detection of the infrastructure is sub-optimal.

University of Novom Sad, Faculty of technical sciences, Geodesy and geomatics contact: cetabajceta@gmail.com 


\section{UNDERGROUND OPTICAL LINES}

The development of optical cables as a telecommunication medium started in the middle of the twentieth century. The first commercial optical line was implemented in Dorset (Great Britain). Fiber optical cables form the backbone of almost every telecommunication network. Today, due to the development of information technology, the use of optical cables is continually increasing.

\section{THE COMPONENTS OF OPTICAL LINES}

The components of a fiber optical cable include: the core, the cladding, the protective casing (figure 1). The core of the fiber optical cable carries the light signals and is constructed mainly of glass and polymer materials.

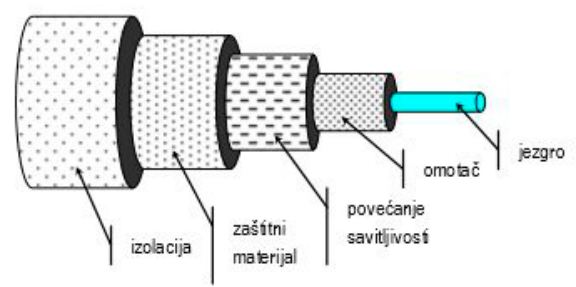

Figure 1. Components of the fiber optic cable

A single optical cable has a relatively small diameter $(12-25 \mathrm{~mm})$ and is rarely buried as such. More commonly optical cables are buried encased in a protective polyethylene (PE) with a diameter of $32-40 \mathrm{~mm}$ (figure 2). In certain cases the PE protective tube that holds the cable is additionally encased in a polyvinyl chloride (PVC) tube with a diameter of $110 \mathrm{~mm}$ giving even greater protection against mechanical and climatic factors (figure 3).

The recommended depth at which optical cables are buried is $1.2 \mathrm{~m}$. In populated areas this depth is often reduced due to a high amount of existing underground infrastructure.

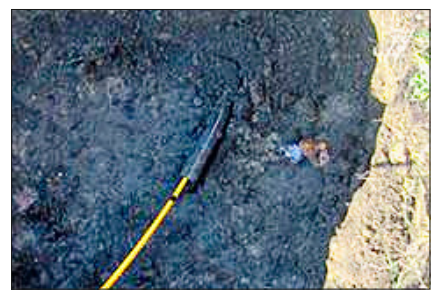

Figure 2. optical cable encased in $40 \mathrm{~mm}$ PE protective tube

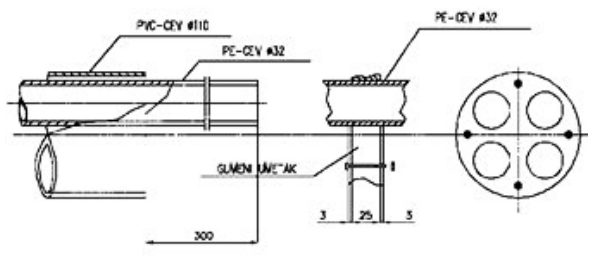

Figure 3. Optical cable encased in a $110 \mathrm{~mm}$ diameter PVC protective tube 


\section{APLICATION OF GROUND-PENETRATIN RADAR}

Ground penetrating radar has a substantial role in the detection of underground infrastructure and acquiring quality data for ground structural analysis. The data acquired can be used for modeling and managing complex systems of underground utilities.

GPR is composed of: an antenna, a control unit, optical encoder, marker, mobile platform (figure 4).

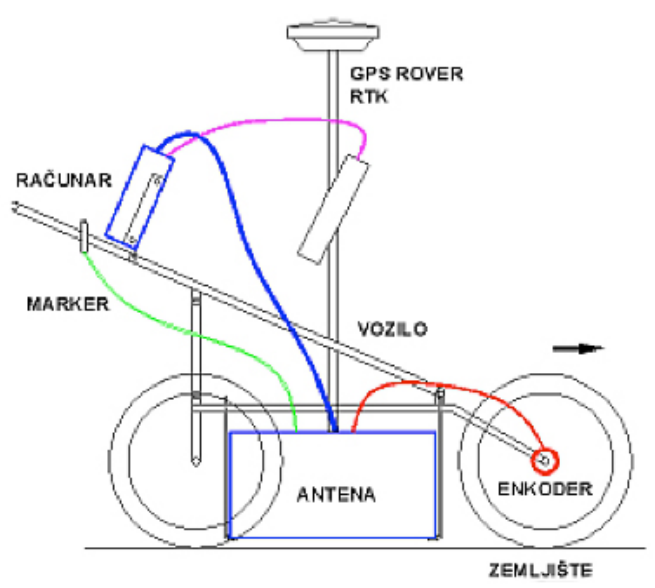

Figure 4. Ground-penetrating radar

While the GPR is in motion the antenna transmits and receives electromagnetic pulses. It measures the time interval between the emission and receiving of the impulse and based on the data calculates the depth of objects or anomalies beneath the surface of the terrain. Important parameters for this study are the spatial resolution and maximum range of an antenna. Spatial resolution refers to the smallest possible dimensions of an object that can be detected. The maximum range of an antenna refers to the largest depth at which an object can be detected. The values of spatial resolution and maximum range calculated for the purpose of this study are displayed in table 1.

Table 1. Spatial resolution and maximum range calculated for this study.

\begin{tabular}{|c|c|c|c|}
\hline $\begin{array}{c}\mathbf{f} \\
(\mathrm{MHz})\end{array}$ & $\begin{array}{c}\text { Spatial resolution } \delta \\
(\mathbf{m m})\end{array}$ & $\begin{array}{c}\text { Maximum range } \\
(\mathrm{m})\end{array}$ & $\begin{array}{c}\text { Real range } \\
(\mathrm{m})\end{array}$ \\
\hline 900 & 4.81 & 1.73 & $<1.00$ \\
\hline 400 & 10.8 & 3.46 & $<2.00$ \\
\hline 200 & 21.6 & 6.92 & $<5.00$ \\
\hline
\end{tabular}




\section{DESCRIPTION OF THE SELECTED LOCATION}

The optical line route is located in the pedestrian zone on Dositeja Obradovićaa square, in between the Faculty of technical sciences, the Faculty of Agriculture and the central building of the University of Novi Sad. The optical line is composed of two separate line routes. One route is encased in a $40 \mathrm{~mm}$ protective $\mathrm{PE}$ tube while the other consists of four $32 \mathrm{~mm}$ PE tubes which are protected with a $110 \mathrm{~mm}$ PVC tube. The selected location holds a large amount of underground infrastructure and installations and for that reason the optical line has been buried at a lower depth then is recommended.

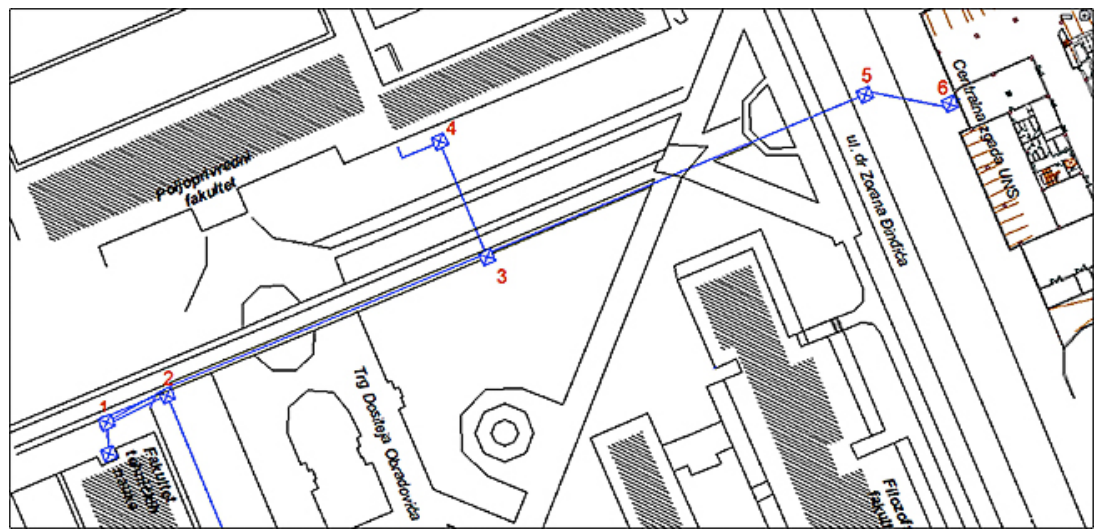

Figure 5. The selected optical line route

\section{RESULTS OF THE STUDY}

Through the use of an antenna with a frequency of $400 \mathrm{MHz}$ the GPR has successfully detected the selected optical line route at a depth of $0.8 \mathrm{~m}$ (figure 6). The detected line was registered in the form of a positive pick. The acquired data shows the optical line in the form of a monolithic object.

Through the use of an antenna with a frequency of $900 \mathrm{MHz}$ the GPR has successfully detected the selected optical line route at a depth of $0.8 \mathrm{~m}$ (figure 6 ). The detected line was registered in the form of a negative pick which indicates that the GPR was able to
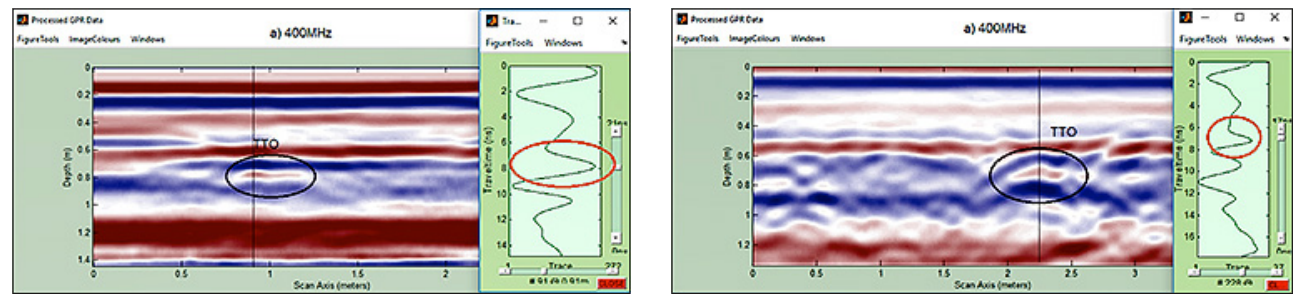

Figure 6. Radargrams aquired using an antenna with $400 \mathrm{MHz}$ frequency 

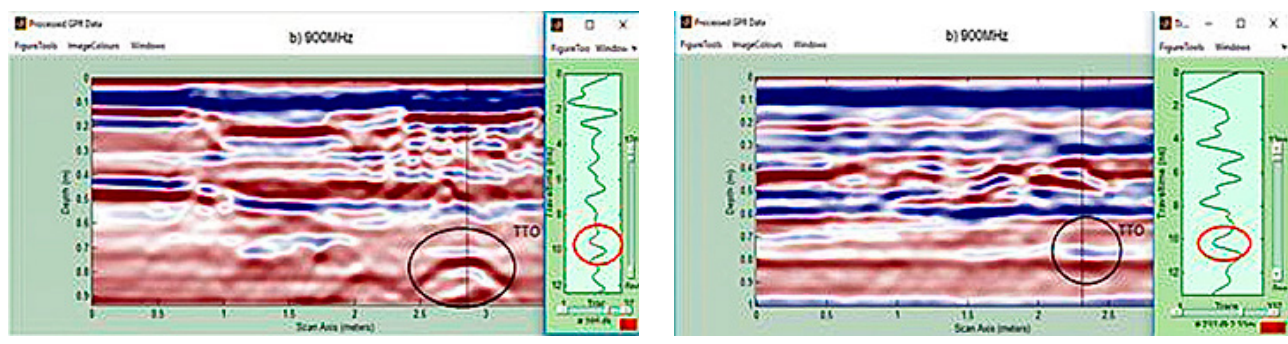

Figure 7. Radargrams aquired using an antenna with $900 \mathrm{MHz}$ frequency

detect a gap inside the protective PVC tube. The acquired data shows the optical line in the form of a monolithic object.

\section{CONCLUSION}

The purpose of the study was to determine analyze the capabilities of GPR technology to detect underground optical lines. The study contains a description of the technology utilized and the type of underground installation detected. The results are displayed in the form of radiograms.

Detection using GPR is possible if the dimensions of the object are not smaller than the spatial resolution of the antenna and if the maximum range of the antenna is smaller than the depth at which the object is buried. The selected optical line has successfully been detected through the use of GPR antennas with frequencies of $400 \mathrm{MHz}$ and $900 \mathrm{MHz}$. Both antennas have sufficient spatial resolution and range to detect the object. The antenna with the frequency of $900 \mathrm{MHz}$ is able to detect gaps inside the PVC tube due to the higher spatial resolution.

\section{REFEFERENCES}

Daniels D. (2004) Ground-Penetrating radar (2nd ed.): Institution of Engineering and Technology, New York:Knoval.

Вукотић Њ. и Зрњић J. (2001): Катастар водова, виша грађевинско-геодетскашкола, Београд.

Hofinghoff J. (2013). Resistive Loaded Antenna for Ground Penetrating Radar Inside a Bottom Hole Assembly.

Jol H. (2008). Ground Penetrating Radar Theory and Applications. Elsevier, Amsterdam: Elsevier.

Ристић, А. (2016): Материјал са предавања и вежби из предмета Детекција објеката подземне инфраструктуре школа, НовиСад.

Заједница Југословенских ПТТ (1998): Збирка прописа из области линија и мрежа (ЛН-ВИИ) Телекомуникационе мреже са оптичким кабловима, Београд. 